\title{
Nitrogen Balance in a Poorly Draining Intensively Cultivated Soil
}

\author{
Nicholas K. MOUSTAKAS*, Constantinos S. KOSMAS \\ Agricultural University of Athens, Faculty of Natural Resources and Agricultural Engineering, Soil Science Department, 75 Iera Odos str., \\ GR11855, Athens, Greece; nmoustakas@aua.gr (*correspondingauthor); ckosm@aua.gr
}

\begin{abstract}
The increasing use of nitrogen in fertilizers has not only increased the productivity of agricultural crops but also the concern for the effects of high $\mathrm{N}$ inputs on the natural environment. Economic, agronomic and environmental concerns have led to greater efforts towards more effective utilization of nitrogenous fertilizers, which can be achieved through a better quantitative understanding of the fate of nitrogen when applied to the soil. So Nitrogen balance was investigated in a poorly draining intensively cultivated soil. Nitrogen inputs and outputs, such as additions by precipitation $\left(\mathrm{N}_{\text {atm }}\right)$, irrigation water $\left(\mathrm{N}_{\text {irr }}\right)$, commercial fertilizers $\left(\mathrm{N}_{\text {fert }}\right)$, mineralization $\left(\mathrm{N}_{\text {min }}\right)$, denitrification $\left(\mathrm{N}_{\text {denitr }}\right)$, volatilization $\left(\mathrm{N}_{\text {gas }}\right)$, capillary rise $\left(\mathrm{N}_{\text {cap }}\right)$, uptake $\left(\mathrm{N}_{\text {upt }}\right)$, residual $\left(\mathrm{N}_{\text {res }}\right)$ and leaching $\left(\mathrm{N}_{\text {leac }}\right)$ were studied and quantified during a period of 72 weeks for two growing crops (maize and wheat). Nitrogen excess or deficit at time ' $t$ ' $(\mathrm{Nt})$ was calculated from the following balance equation: $\mathrm{Nt}=$ $\mathrm{N}_{\text {res }}+\mathrm{N}_{\text {arm }}+\mathrm{N}_{\text {irr }}+\mathrm{N}_{\min }+\mathrm{N}_{\text {fert }}+\mathrm{N}_{\text {cap }}-\mathrm{N}_{\text {upt }}-\mathrm{N}_{\text {denitr }}-\mathrm{N}_{\text {gas }}-\mathrm{N}_{\text {leac. }}$. Existing models were used after proper adjustments to calculate these fluxes. Only a single model, based on soil temperature at $60 \mathrm{~cm}$ and $\mathrm{NO}_{3}-\mathrm{N}$ concentration in ground water was developed for the estimation of denitrification at the ground water boundary. The calculated values satisfactorily matched the respective experimental data. The results shown that the greater part of the applied nitrogen fertilizer was lost to ground water during the winter causing considerable environmental concern. For sustainable land use, inputs and outputs of nutrients must be balanced in order to avoid negative impacts on the environment, especially in intensively exploited agricultural ecosystems.
\end{abstract}

Keywords: groundwater pollution, leaching, nitrogen cycle, temperature model

\section{Introduction}

Much research has been carried out over the years into the fate and efficiency of nitrate-nitrogen $\left(\mathrm{NO}_{3}-\mathrm{N}\right)$ in agricultural ecosystems. The increasing use of nitrogen in fertilizers has not only increased the productivity of agricultural crops but also the concern for the effects of high $\mathrm{N}$ inputs on the natural environment (Janzen et al., 2003; Eickout et al., 2006; Ross et al., 2008). This concern has focused on the concentration of $\mathrm{NO}_{3}{ }^{-} \mathrm{N}$ in surface water and its leaching into groundwater, its release into the atmosphere as ammonia and its subsequent deposition onto the soil surface, leading to soil acidification and eutrophism (Merrington et al., 2002). Nitrous oxide is also produced, which contributes as a greenhouse gas to global warming and to destruction of the ozone layer (Crutzen, 1981; Franzluebbers, 2007; Herrero et al., 2010). These losses are connected to the nitrogen cycle in such a way that an attempt to reduce one source of $\mathrm{N}$-pollutant may induce an increase in another. Consequently, an integrated study of such pollutants is required. Such work will lead to the development of local, national and international strategies for minimizing $\mathrm{N}$ losses from agricultural ecosystems. The EEC directive 91/676/EEC requires member states to minimize direct and indirect water pollution by $\mathrm{NO}_{3}-\mathrm{N}$ from agricultural sources and to implement measures to avoid further pollution. Thus, the farmer can more accurately determine the amount of fertilizer to use on a crop to manage yield yet avoid over fertilization, while political decision makers can identify agricultural best practices

Different models of nitrogen balance describe the nitrogen flows (inputs and outputs) in the soil-water-plantatmosphere system (Vereecken et al., 2016). These models vary in their conceptualization, complexity and the concerns, which they address. Studies on $\mathrm{N}$ balance have been reported in several long-term experiments (Davis et al., 2003; Ross et al., 2008; Pieri et al., 2011). Accurate measurement of $N$ balance is, however, difficult because of the complexity of measurement of some parameters and increased time, labor, and cost constraints. Differences in soils, climatic conditions, crop species, and management practices can influence $\mathrm{N}$ balance in various agro-ecosystems due to variations in $\mathrm{N}$ inputs, outputs, and retention in the soil (Meisinger and Randall, 1991; Ross et al., 2008; Pieri et al., 2011).

Recent research on dealing with water pollution from $\mathrm{NO}_{3}{ }^{-} \mathrm{N}$ has focused on the factors and processes, which regulate the concentration of $\mathrm{N}$ in the root zone. Economic, agronomic and environmental concerns have led to greater efforts towards more effective utilization of nitrogenous 
fertilizers, which can be achieved through a better quantitative understanding of the fate of nitrogen when applied to the soil.

The aim of the present study was the quantitative assessment of nitrogen inputs and outputs for a poorly draining intensively cultivated soil situated on an alluvial plain formed on lake deposits, with the intent of sustainable utilisation of nitrogenous fertilizers and correspondingly reducing environmental pollution.

\section{Materials and Methods}

\section{Location and soilclassification of the experimental site}

The soil studied is located in the drained Kopaida basin, Veotia prefecture, Greece $\left(38^{\circ} 32^{\prime}\right.$ N $23^{\circ} 06$ E, $110 \mathrm{~m}$ asl), in an alluvial plain of lake deposits, intensively cultivated with maize, wheat and cotton. The soil has a perched water table, is very poorly draining and is classified as a Humic Fluvaquent, fine mixed calcaric (Soil Survey Staff, 1975). The water table level is influenced by local use of irrigation (lateral flow) and usually fluctuates at a depth of $85-145 \mathrm{~cm}$.

\section{Experimental design and treatments}

The experimental plot was divided into three rows of four plots, each of $12 \mathrm{~m}^{2}$, with $0.5 \mathrm{~m}$ between plots and $1 \mathrm{~m}$ between rows. The experiment followed the complete randomized block design, with four levels of $\mathrm{N}$ and three replicates.

Two different cultivation periods with different crops were studied for 72 consecutive weeks (504 days). The experiment started in March and finished in November the following year. Table 1 presents the cultivation periods and the weeks with the corresponding treatments. In the first cultivation period, March to October, maize was grown 'Pioneer', while in the following, November to July, wheat was grown 'Mexicali-81'.

For maize cultivation, the following $\mathrm{N}$ treatments were applied: $0,95,193$ and $287 \mathrm{~kg} \mathrm{~N}^{-1} \mathrm{C}^{-1}$, while those for wheat were $0,40,70,80$ and $128 \mathrm{~kg} \mathrm{~N} \mathrm{ha}^{-1}$. Ammonium phosphate (20-1010) was used for both crops. The fertilizer was incorporated into the upper $15 \mathrm{~cm}$ of the soil during sowing. For maize, irrigation

Table 1.Treatments through the study periods

\begin{tabular}{ccc}
\hline & $1^{\text {st }}$ growing period & \\
\hline Week & Month & Treatment \\
\hline 1 & March $1^{\text {st }}$ & start \\
2 & March $15^{\text {th }}$ & Sampling \\
8 & April $26^{\text {th }}$ & Sowing \\
14 & June $10^{\text {th }}$ & Sampling \\
16 & July $25^{\text {th }}$ & Irrigation \\
19 & July $13^{\text {th }}$ & Irrigation \\
\hline 24 & July $29^{\text {th }}$ & Irrigation \\
\hline 26 & August $18^{\text {th }}$ & Irrigation \\
\hline 28 & September $15^{\text {th }}$ & Sampling \\
\hline 31 & October $4^{\text {th }}$ & Harvest \\
\hline & $2^{\text {nd }}$ growing period & \\
\hline Week & Month & Treatment \\
38 & November $1^{\text {th }}$ & Sampling \\
45 & November $22^{\text {th }}$ & Sowing \\
\hline 55 & March $23^{\text {th }}$ & Sampling \\
68 & June $23^{\text {th }}$ & Harvest \\
69 & July $3^{\text {th }}$ & Sampling \\
72 & July $24^{\text {th }}$ & End \\
\hline
\end{tabular}

was applied by sprinkler on $25 / 6,13 / 7,29 / 7,18 / 8$ with 180,150 , $160,150 \mathrm{~m}^{3} \mathrm{H}_{2} \mathrm{O} \mathrm{ha}^{-1}$, respectively (Table 1). At the end of the cultivation period, the aerial parts of the crop were removed from each plot and the plant mass divided into leaves/stems and seeds. These were dried to constant weight at $65^{\circ} \mathrm{C}$, weighed and the dry weight per ha calculated. The Kjeldahl method was used to determine the total $\mathrm{N}$ content.

\section{Measurements of soilphysical and chemical properties}

Soil samples were taken from each horizon in each experimental plot. The samples were transferred to the laboratory, air-dried, and ground to pass a $2 \mathrm{~mm}$ sieve. This soil fraction was used to determine: particle size distribution by hydrometric method; organic matter content using a modified Walkley-Black method; calcium carbonate equivalence by $\mathrm{CO}_{2}$ release on reaction with $\mathrm{HCl}$; total soil $\mathrm{N}$ by Kjedahl, $\mathrm{pH}$ in 1:1 soil:water suspension; Bulk density using appropriate metal cylinders; field capacity and water content at wilting point by use of Richard's apparatus. All the above methods are described in detail in Soil Survey Laboratory Methods (2014).

For the requirements of the water balance model (WATBAL) (Berghuijs-van Dijk, 1985; Yates, 1996) a) field capacity and wilting point were calculated for two soil layers: 0-38 and 38-109 $\mathrm{cm}, \mathrm{b})$ Saturated water hydraulic conductivity in the field for three layers, 0-38, 38-72 and 72-109 cm, and for 38-109 cm, were determined using the crust infiltration method (Bouma and Benning, 1972). The measured soil physical and chemical properties are given in Table 2 .

Composite soil samples were taken before sowing from each plot (from three sites per plot) for 0-15, 15-30, 30-60, 60-90 cm three times during the each cultivation period before sowing, in the middle of the growing season and after harvest (Table 1). In order to show the variation of $\mathrm{NO}_{3}^{-}-\mathrm{N}^{2}$ and $\mathrm{NH}_{4}^{+}-\mathrm{N}$ with time, these $\mathrm{N}$ forms were determined by extraction with $2 \mathrm{M} \mathrm{KCl} . \mathrm{NH}_{4}^{+}-\mathrm{N}$ was determined using the indophenol blue method, and $\mathrm{NO}_{3}-\mathrm{N}$ by cadmium reduction method (Keeney and Nelson, 1982). For monitoring $\mathrm{NO}_{3}-\mathrm{N}$ and $\mathrm{NH}_{4}^{+}-\mathrm{N}$ in the soil solution, at the experimental site, vertical pipes with ceramic cups at their lower end, connected with a tube to a pump, were installed at a depth of $80 \mathrm{~cm}$ in each plot. The soil solution was sampled by applying suction of $250 \mathrm{~mm} \mathrm{Hg}$ every two weeks and the concentration of $\mathrm{NO}_{3}^{-}-\mathrm{N}^{2}$ and $\mathrm{NH}_{4}^{+}-\mathrm{N}$ determined.

The depth of the water table was assessed using piezometers installed in each plot. Meteorological data were sourced from the national meteorological station at Aliartos, located $2 \mathrm{~km}$ from the experimental field.

\section{$E T_{o}$ and $E T_{a}$ calculations}

Potential evapotranspiration $\left(\mathrm{ET}_{\mathrm{o}}\right)$ was calculated using the Penman-Monteith equation (Allen et al., 1998), while actual evapotranspiration was calculated from the equation: $\mathrm{ET}_{\mathrm{a}}=\mathrm{E}_{\mathrm{a}}+$ TRM, where TRM is the true transpiration rate $\left(\mathrm{mm} \mathrm{d}^{-1}\right)$ and $\mathrm{E}_{a}$ the true evaporation rate $\left(\mathrm{mm} \mathrm{d}^{-1}\right)$. $\mathrm{E}_{\mathrm{a}}$ was calculated using the equation:

$$
E_{a}=E_{o} e^{\frac{(-0.4 L A I)(C M C-S M A D)}{(S M O-S M A D)}},
$$

where LAI is the leaf area index $\left(\mathrm{cm}^{3} \mathrm{~cm}^{-3}\right), \mathrm{CMC}$ the water content of the surface horizon, $\mathrm{E}_{\mathrm{o}}$ the open pan evaporation rate, SMO the saturated water content, SMAD the water content of the respective air-dried soil (Driessen, 1988). The LAI at different growth stages of crops was determined using a leaf area analyzer (LI-COR 2000). 
Table 2. Selected physicochemical properties of the studied soil

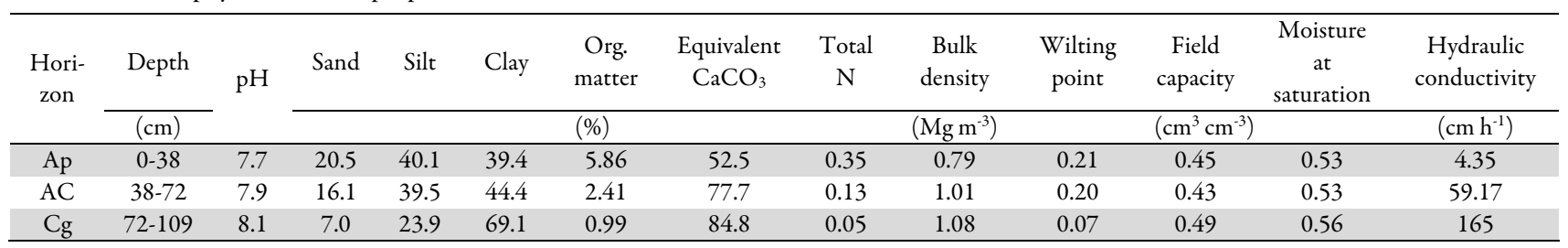

\section{Soil temperature measurements and calculations}

Soil temperature was measured using a thermocouple (FeConstantan) installed in the field at depths of 5, 15, 30 and 60 $\mathrm{cm}$. Soil temperature at different depths was calculated on a daily basis using the following equation: $T_{(\mathrm{z}, t)}=\mathrm{T}_{\mathrm{m}}+\mathrm{A}_{\mathrm{e}} \mathrm{z}^{(\mathrm{z}-\mathrm{dt})} \sin [\omega(\mathrm{t}-$ $\left.t_{0}\right)-z / d$, where $T_{(z, t)}$ is the temperature at depth $z$ at time $t$ (Scott, 2000). The equation describes a curve for temperature behaving as a sine wave with angular frequency of $\omega=2 \pi / p$ (where $\rho$ is the period, $24 \mathrm{~h}$ for daily wave, 365 days for yearly), amplitude $\mathrm{A}_{\mathrm{o}}$ around the temperature $\mathrm{T}_{\mathrm{m}}$ which characterizes the soil, and $\mathrm{d}$ is the damping depth. The soil temperature was expressed on a weekly basis for use in WATBAL model.

\section{$N_{\text {min }}$ determination}

Mineralization of organic $\mathrm{N}\left(\mathrm{N}_{\min }\right)$ was determined by soil incubation experiments at $7,20,30$ and $35^{\circ} \mathrm{C}$ for 28 weeks following the procedure described by Stanford and Smith (1972). Residual nitrogen in the soil after incubation was removed by successive washing with $10 \mathrm{ml}$ of $0.01 \mathrm{M} \mathrm{CaCl}_{2}$. Then $25 \mathrm{ml}$ of nutrient medium was added containing $0.002 \mathrm{M}$ $\mathrm{CaSO}_{4} 2 \mathrm{H}_{2} \mathrm{O}, 0.002 \mathrm{M} \mathrm{MgSO}_{4}, 0.005 \mathrm{M} \mathrm{Ca}\left(\mathrm{H}_{2} \mathrm{PO}_{4}\right) 2 \mathrm{H}_{2} \mathrm{O}$ and $0.0025 \mathrm{M} \mathrm{K}_{2} \mathrm{SO}_{4}$. There were two replicates for each sample. The samples were placed in an incubator and after two weeks incubation, the tubes were removed, and soil samples were extracted with successive applications of $10 \mathrm{ml}$ of $0.01 \mathrm{M} \mathrm{CaCl}_{2}$ to a total of $100 \mathrm{ml}$ in which $\mathrm{NO}_{3}^{-}-\mathrm{N}$ and $\mathrm{NH}_{4}^{+}-\mathrm{N}$ were determined. This process was repeated after 5, 7, 8 and 9 weeks, and the cumulative amounts of $\mathrm{NO}_{3}-\mathrm{N}$ and $\mathrm{NH}_{4}^{+}-\mathrm{N}\left(\mathrm{N}_{\mathrm{cum}}\right)$ mineralized between weeks were calculated for the laboratory estimate. $\mathrm{N}_{\text {aum }}$ was also determined at field conditions using 1800 $\mathrm{g}$ of soil $(<2 \mathrm{~mm})$ uniformly mixed with an equal quantity of quartz sand $(1 \mathrm{~mm})$ and placed in plastic cylinders of $40 \mathrm{~cm}$ height and $12 \mathrm{~cm}$ diameter, each with a mesh at the base to prevent loss of material and a funnel for collection of soil leachate. The columns were placed in the field such that its upper surface was at the same level as the field soil surface. Soil temperature and moisture of the columns were measured at a depth of 5 and 30 $\mathrm{cm}$ using thermocouples and soil moisture meters. New columns were prepared for the second period. For field determination of $\mathrm{N}_{\mathrm{aum}}$, the same procedure was followed as for the laboratory determination.

$\mathrm{N}_{\min }$ was calculated using a first-order reaction equation proposed by Stanford and Smith (1972): $\mathrm{N}_{\mathrm{cum}}=\mathrm{N}_{\min }\left(1-\exp ^{-\mathrm{kt}}\right)$, where $\mathrm{N}_{\mathrm{cum}}$ is the cumulative $\mathrm{N}$-mineralization for incubation time $t, N_{\min }$ is the potential mineralization, and $k$ the constant for mineralization rate. $\mathrm{N}_{\min }$ and $\mathrm{k}$ were derived from non-linear regression, since this gives more accurate results (Talpaz et al., 1981) than with the techniques originally proposed by Stanford and Smith (1972). Losses of $\mathrm{N}\left(\mathrm{N}_{\mathrm{ggs}}\right)$ in the form of gaseous ammonia $\left(\mathrm{NH}_{3}\right)$ from the $\mathrm{N}$ applied in fertilizer were measured in a separate identical experiment in the same field following the procedure proposed by Kissel et al. (1977). $\mathrm{NH}_{3}$ gas lost from the soil surface was forced to pass through a chemical trap containing $175 \mathrm{ml}$ of $2 \% \mathrm{H}_{3} \mathrm{BO}_{3}$ for $10 \mathrm{~min}$. The amount of $\mathrm{NH}_{3}$ trapped was determined by titration with $\mathrm{HCl}$ (Keeney and Nelson, 1982).

In order to determine the amount of $\mathrm{N}$ deposited from the atmosphere $\left(\mathrm{N}_{\mathrm{am}}\right)$, rain collectors were located in the field. After each rainfall event, the volume of collected water and its $\mathrm{NO}_{3}-\mathrm{N}$ content were determined. In addition, the $\mathrm{NO}_{3}-\mathrm{N}$ concentration in irrigation water $\left(\mathrm{N}_{\mathrm{ir}}\right)$ was determined before irrigating.

\section{WATBAL model requirements}

The soil profile was divided into two layers (0-38, 38-109 $\mathrm{cm}$ ) in accordance with the requirements for WATBAL model for determining the water balance on a weekly basis, adjusted for the level of the water table, the measured actual evaporation, and the calculated evapotranspiration. According to the model, the soil moisture in the first zone was uniformly distributed, while that in the second increased linearly with depth until reaching saturation at the level of the water table. The physical properties of the soil taken into account in applying the model were:

$>$ The depth of the first $(38 \mathrm{~cm})$ and the second $(71 \mathrm{~cm})$ layers

$>$ Soil water content at wilting point of the two layers,

$>$ Soil water content at field capacity of the two layers,

$>$ Soil moisture content at saturation of the two layers,

$>$ The balance equation for the first layer can be written as: and for the second layer as: $\mathrm{dM} 2 / \mathrm{dt}=\mathrm{fc}(\mathrm{M} 2)+$ $\mathrm{ft}(\mathrm{M} 1)+\mathrm{fd}(\mathrm{M} 1)$, where PR is rainfall, $\mathrm{ET}_{\mathrm{a}}$ is actual evapotranspiration, $\mathrm{fc}(\mathrm{M} 2)$ is water from the second layer by capillary transfer, $\mathrm{ft}(\mathrm{M} 1)$ the transfer of water from the first to second layer, $\mathrm{fd}(\mathrm{Ml})$ the drainage of water from the first layer.

\section{$N_{\text {lec }}$ calculation}

The amount of $\mathrm{NO}_{3}{ }^{-} \mathrm{N}$ leached from the root zone $\left(\mathrm{N}_{\text {leac }}\right)$ was calculated using the equation $\mathrm{N}_{\mathrm{lac}}=\left[\left(\mathrm{DP} / \mathrm{MC} \times \mathrm{CNO}_{3}\right)\right]$ $\times \mathrm{R}$, where DP is the amount of water removed from the root zone calculated from the WATBAL model, $\mathrm{CNO}_{3}$ and $\mathrm{MC}$ are the $\mathrm{NO}_{3}{ }^{-} \mathrm{N}$ concentration and soil moisture, respectively, in the root zone, and $\mathrm{R}$ is a loss factor. $\mathrm{R}$ was calculated from $\mathrm{NO}_{3}{ }^{-} \mathrm{N}$ leaching of undisturbed soil. For this purpose, five columns 40 $\mathrm{cm}$ in length and $20 \mathrm{~cm}$ in diameter with undisturbed soil were taken to the laboratory. Leaching of the columns was carried out using $4 \mathrm{~L}$ of water per column and the $\mathrm{NO}_{3}{ }^{-}-\mathrm{N}$ in leachate was measured. The $\mathrm{NO}_{3}^{-}-\mathrm{N}$ loss in leachate was then calculated as $\mathrm{N}_{\text {lac }}=\left[\left(\mathrm{DP} / \mathrm{MC} \times \mathrm{CNO}_{3}\right)\right]$. The amount of $\mathrm{NO}_{3}^{-}-\mathrm{N}$ leached was less than that calculated from the equation due to the presence of immobile water (Vanclooster et al., 1992; Manzoni and Porporato 2009). The difference was calculated as a percentage and used as an estimate of $R$ 


\section{Nt calculation}

The $\mathrm{N}$ inputs into the system, namely $\mathrm{N}_{\text {res }}, \mathrm{N}_{\text {atm }}, \mathrm{N}_{\text {fert, }}, \mathrm{N}_{\text {cap, }}$, and the losses from $\mathrm{N}_{\text {denitr, }} \mathrm{N}_{\text {gas }}, \mathrm{N}_{\text {upt }}$ and $\mathrm{N}_{\text {leac }}$ were quantatively determined for 72 consecutive weeks and the deficit or surplus $\mathrm{Nt}$ at time $\mathrm{t}$ was calculated as:

$\mathrm{Nt}=\mathrm{N}_{\mathrm{res}}+\mathrm{N}_{\mathrm{atm}}+\mathrm{N}_{\text {irr }}+\mathrm{N}_{\text {min }}+\mathrm{N}_{\text {fert }}+\mathrm{N}_{\mathrm{cap}}-\mathrm{N}_{\text {upt }}-\mathrm{N}_{\text {denitr }}-$ $\mathrm{N}_{\text {gas }}-\mathrm{N}_{\text {leac }}$

\section{Statistical analysis}

Statistical analysis was carried out using STATISTICA (StatSoft 1995).

\section{Results and Discussion}

\section{Soil temperature}

The soil temperature followed a sine wave curve at all depths. The daily temperature difference at $5 \mathrm{~cm}$ was from $3.5-$ $13.0{ }^{\circ} \mathrm{C}$, while that for $60 \mathrm{~cm}$ was less than $0.5^{\circ} \mathrm{C}$. The soil temperature varied throughout the year, with an average value of $16.5^{\circ} \mathrm{C}$ depth overall. Although soil temperature is related to soil water, physical soil properties, climate and vegetation cover, the curve satisfactorily described the soil temperature for the studied depths. Fig. 1(a) shows the temperature recorded at different times and the changes at a depth of $15 \mathrm{~cm}$ and the values predicted by the equation: $T_{(\mathrm{z}, \mathrm{t})}=\mathrm{T}_{\mathrm{m}}+\mathrm{A}_{\mathrm{o}} \mathrm{e}^{(\mathrm{z}-\mathrm{dt})} \sin [\omega(\mathrm{t}-$ $\left.t_{0}\right)-/ d$. This equation can be used to satisfactorily predict soil temperature of this soil.

\section{Soil moisture}

The soil moisture in the root zone $(0-38 \mathrm{~cm})$ ranged from $0.198 \mathrm{~cm}^{3} \mathrm{~cm}^{-3}$ (approximately the wilting point of this soil) to
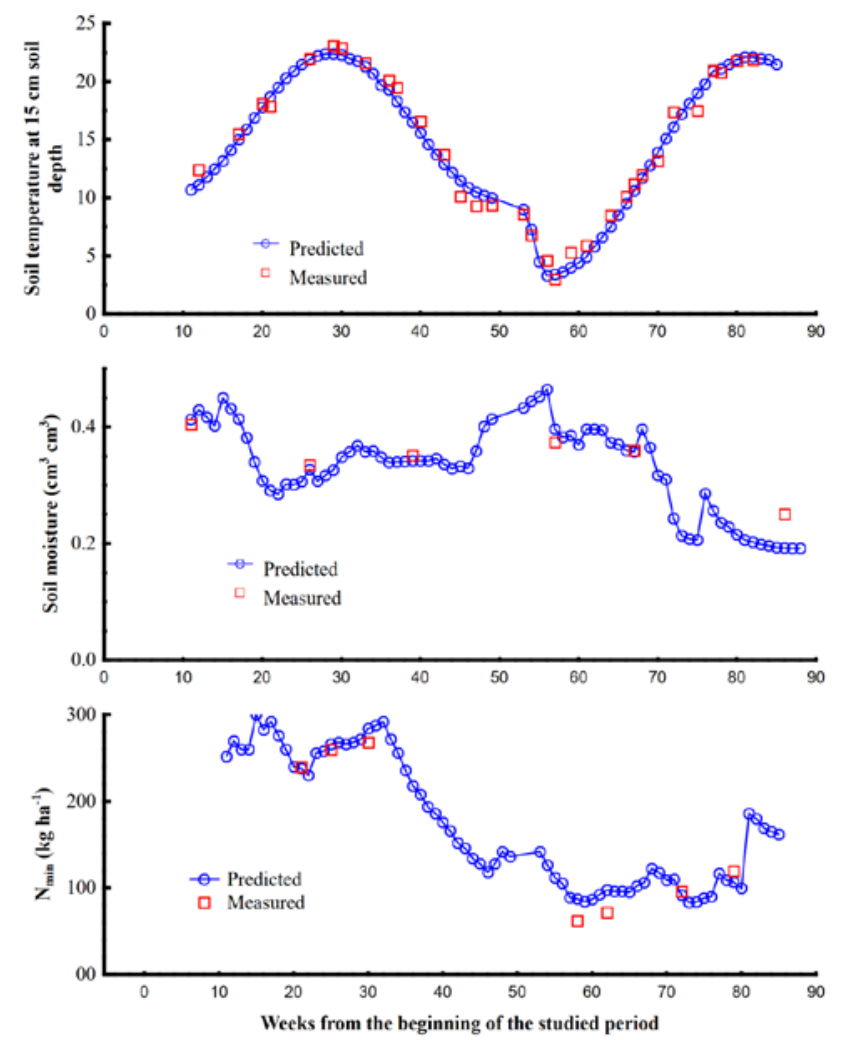

Fig. 1. Predicted and measured values for: (a) soil temperature at $15 \mathrm{~cm},(\mathrm{~b})$ soil moisture at rooting depth $(0-38 \mathrm{~cm})$ and $(\mathrm{c})$ $\mathrm{N}_{\text {min }}$ mineralized at rooting depth $(0-38 \mathrm{~cm})$, for 72 weeks' continuous study
$0.46 \mathrm{~cm}^{3} \mathrm{~cm}^{-3}$ (Fig. 1(b)) depending on evapotranspiration. The soil moisture during the first cultivation period was relatively high since the water table was between 85 and $145 \mathrm{~cm}$ (due to irrigation method-lateral flow) (Fig. 2). During the next cultivation period, partially during the summer, the soil remained dry due to the unusually dry winter, resulting in the water table dropping below $170 \mathrm{~cm}$ depth. The WATBAL model predicted soil moisture relatively well for the root zone, except in the summer of the second cultivation period, for which soil moisture was underestimated by $30 \%$ (Fig. 1(b)). This difference is likely to be the result of the mulch zone, which was created in the top $5 \mathrm{~cm}$ of soil from the wheat crop when evapotranspiration was very high.

$N$ addition by rain and irrigation $\left(N_{a t m}+N_{i r}\right)$

The total contribution of $\mathrm{N}_{\mathrm{atm}}+\mathrm{N}_{\text {irr }}$ was calculated as $10 \mathrm{~kg}$ $\mathrm{Nha}^{-1}$ year $^{-1}$.

\section{$N$ Removal by crop uptake $\left(N_{\text {upt }}\right)$}

The dry weight of crop plants and the total $\mathrm{N}$ uptake by crops are shown in Table 3. The result show that $\mathrm{N}$ uptake by the two crops was significantly greater than that applied in nitrogenous fertilizer, reflecting the significant contribution to crop nutrition, particularly by $\mathrm{N}_{\text {min. }}$

\section{$N$ loss due to denitrification $\left(N_{\text {den }}\right)$}

The losses of $\mathrm{N}$ as $\mathrm{N}_{\text {den }}$ in this particular soil were expected to be high due to (a) the relatively high water table (Fig. 2), (b) the high $\mathrm{pH}(>7.7)$ (Table 2) and (c) the high temperature in the denitrification zone $\left(7.5-21^{\circ} \mathrm{C}\right.$ ) (Fig. 3). The soil layers below the root zone $(>38 \mathrm{~cm})$ remained at moisture contents above their field capacity. The WATBAL model showed that capillary water contributed significantly to the evapotranspiration demands of root zone soil from starting to the end of studied period (Fig. 2).

The concentration of $\mathrm{NO}_{3}{ }^{-}-\mathrm{N}$ in soil solution sampled extracting by ceramic cups was lower than that of groundwater. The difference was related to the temperature at $60 \mathrm{~cm}$. The $\mathrm{NO}_{3}{ }^{-}-\mathrm{N}$ concentration in the soil solution was approximately 25 times lower than that of the groundwater during the summer, when the average temperature at $60 \mathrm{~cm}$ was $19.8^{\circ} \mathrm{C}$. In contrast, during winter when the average temperature at 60

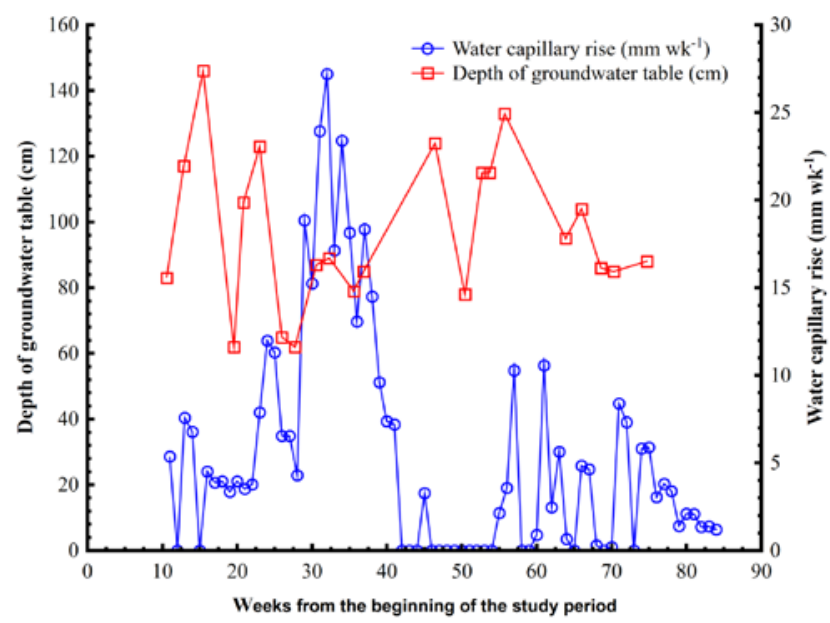

Fig. 2. Fluctuation of ground water table and amount of capillary water raise to the root zone $\left(\mathrm{mm} \mathrm{week}^{-1}\right)$ for the study period of 72 weeks 
Table 3. Dry matter of shoots, total yields and total $\mathrm{N}$ uptake by maize and wheat under different $\mathrm{N}$ treatments

\begin{tabular}{|c|c|c|c|c|c|c|c|}
\hline \multirow{3}{*}{$\begin{array}{c}\text { N Applied } \\
\mathrm{kg} \mathrm{ha}^{-1}\end{array}$} & \multicolumn{3}{|c|}{ Maize } & \multirow{3}{*}{$\begin{array}{c}\text { N Applied } \\
\mathrm{kg} \mathrm{ha}^{-1}\end{array}$} & \multicolumn{3}{|c|}{ Wheat } \\
\hline & $\begin{array}{c}\text { Shoot dry } \\
\text { matter }\end{array}$ & $\begin{array}{c}\text { Grain dry } \\
\text { matter }\end{array}$ & $\begin{array}{l}\text { Total N } \\
\text { uptake }\end{array}$ & & $\begin{array}{c}\text { Shoot dry } \\
\text { matter }\end{array}$ & $\begin{array}{c}\text { Grain dry } \\
\text { matter }\end{array}$ & $\begin{array}{c}\text { Total N } \\
\text { uptake }\end{array}$ \\
\hline & \multicolumn{2}{|c|}{$\mathrm{Mg} \mathrm{ha}^{-1}$} & $\mathrm{~kg} \mathrm{ha}^{-1}$ & & \multicolumn{2}{|c|}{$\mathrm{Mg} \mathrm{ha}^{-1}$} & $\mathrm{~kg} \mathrm{ha}^{-1}$ \\
\hline 0 & $18.5 \mathrm{a}^{*}$ & $12.7 \mathrm{a}$ & $255.4 \mathrm{a}$ & 0 & $5.6 a$ & $2.9 \mathrm{a}$ & $88.7 \mathrm{a}$ \\
\hline 95 & $18.7 \mathrm{a}$ & $13.5 \mathrm{a}$ & $296.3 \mathrm{ab}$ & 47 & $7.0 \mathrm{ab}$ & $3.7 \mathrm{ab}$ & $151.8 \mathrm{ab}$ \\
\hline 193 & $20.1 \mathrm{a}$ & $14.0 \mathrm{a}$ & $296.2 \mathrm{ab}$ & 80 & $8.2 \mathrm{ab}$ & $3.6 \mathrm{ab}$ & $168.8 \mathrm{ab}$ \\
\hline 287 & $20.6 \mathrm{a}$ & $14.1 \mathrm{a}$ & $316.9 \mathrm{~b}$ & 180 & $9.9 \mathrm{~b}$ & $5.1 \mathrm{~b}$ & $205.5 \mathrm{~b}$ \\
\hline
\end{tabular}

${ }^{*}$ Numbers in the same column followed by the same letter are not significantly different according to Duncan multiple range test at $\mathrm{p}<0.05$

$\mathrm{cm}$ was $6.5^{\circ} \mathrm{C}$, the $\mathrm{NO}_{3}^{-}-\mathrm{N}$ concentration in the soil solution was 1.2 fold lower than that of groundwater. The groundwater level varied from $85-135 \mathrm{~cm}$ between winter and summer. The soil moisture at sampled depths remained relatively stable (46.8-47.9\%) due to the irrigation method.

Therefore, soil oxygenation did not differ significantly between summer and winter. Consequently, the only factor contributing to loss of $\mathrm{N}$ during the summer months was the increase in reduction by micro-organisms due to increasing temperature. Another possible factor which could have contributed to $\mathrm{N}$ loss during this period is immobilisation of $\mathrm{N}$ by micro-organisms, which also increases due to increasing temperature. The presence of roots and their decomposition at the sampled depth $(80 \mathrm{~cm})$ was insignificant. Therefore the immobilisation of $\mathrm{N}$ at this depth is considered negligible.

During the summer, when the soil temperature at $60 \mathrm{~cm}$ was $18-21^{\circ} \mathrm{C}$, the activity of denitrifying micro-organisms was very high and the $\mathrm{NO}_{3}-\mathrm{N}$ concentration in the soil solution of the denitrifying zone was less than $1 \mathrm{mg} \mathrm{L}^{-1}$. However, when the temperature fell below $7.1{ }^{\circ} \mathrm{C}$, the $\mathrm{NO}_{3}-\mathrm{N}$ concentration in the soil solution of this zone was $>9 \mathrm{mg} \mathrm{L}^{-1}$. The average $\mathrm{NO}_{3}-\mathrm{N}$ concentration of groundwater for the study period was $11.76 \pm 3.2 \mathrm{mg} \mathrm{L}^{-1}(\mathrm{n}=48)$.

The $\mathrm{NO}_{3}-\mathrm{N}$ concentration in the soil solution in the denitrifying zone, regardless of $\mathrm{N}$ treatment, followed an exponential curve dependent on the soil temperature at $60 \mathrm{~cm}$ (Fig. 3). The equations shown in Fig. 3 are of first-order reaction kinetics, similar to those describing the decomposition of organic matter $\left(\mathrm{Y}=\mathrm{A} \mathrm{e} \mathrm{e}^{(-\mathrm{kt})}\right)$. The constant ' $\mathrm{k}$ ' (average $\mathrm{k}=$ 0.1546 , with standard deviation $2 \times 10^{-3}$ ) and the value of ' $\mathrm{A}$ ' (average $\mathrm{A}=23.57$, with standard deviation 0.103 ) were independent of $\mathrm{N}$ treatment. The value of $\mathrm{A}$ is approximately twice the average $\mathrm{NO}_{3}-\mathrm{N}$ concentration in groundwater (i.e. $2 \times 11.76=23.5)$. Therefore, the equation for estimation of denitrification can be written as: $\mathrm{C}_{\mathrm{ss}}=2 \mathrm{C}_{\mathrm{gw}} \mathrm{e}^{(-\mathrm{kt})}$, where $\mathrm{C}_{\mathrm{ss}}$ and $\mathrm{C}_{\mathrm{gw}}$ are the $\mathrm{NO}_{3}-\mathrm{N}$ concentration in the soil solution (at 80 $\mathrm{cm}$ ) and groundwater, respectively. The $\mathrm{NO}_{3}-\mathrm{N}$ concentration in the soil solution of the denitrifiying zone was calculated per week using the above equation, the temperature at $60 \mathrm{~cm}$ and the $\mathrm{NO}_{3}-\mathrm{N}$ concentration in groundwater. The $\mathrm{N}$ transported to the atmosphere was calculated cumulatively as the product of the differences $\left(\mathrm{C}_{\mathrm{ss}}-\mathrm{C}_{\mathrm{gv}}\right)$ and the quantity of rising capillary water calculated by the WATBAL during the execution of the experiment.

The greatest losses of $\mathrm{N}$ recorded during the summer months can be attributed to the high soil temperatures and high quantities of capillary water moving to the rhizosphere during this period (Fig. 4). The total loss of $\mathrm{N}$ due to denitrification during the first cultivation period $18 \mathrm{~kg} \mathrm{ha}^{-1}$, while for the second it was only $7.1 \mathrm{~kg} \mathrm{ha}^{-1}$ The total $\mathrm{N}$ lost to the atmosphere for the 37 week period of capillary rise calculated by WATBAL was $25.3 \mathrm{kgha}^{-1}$.

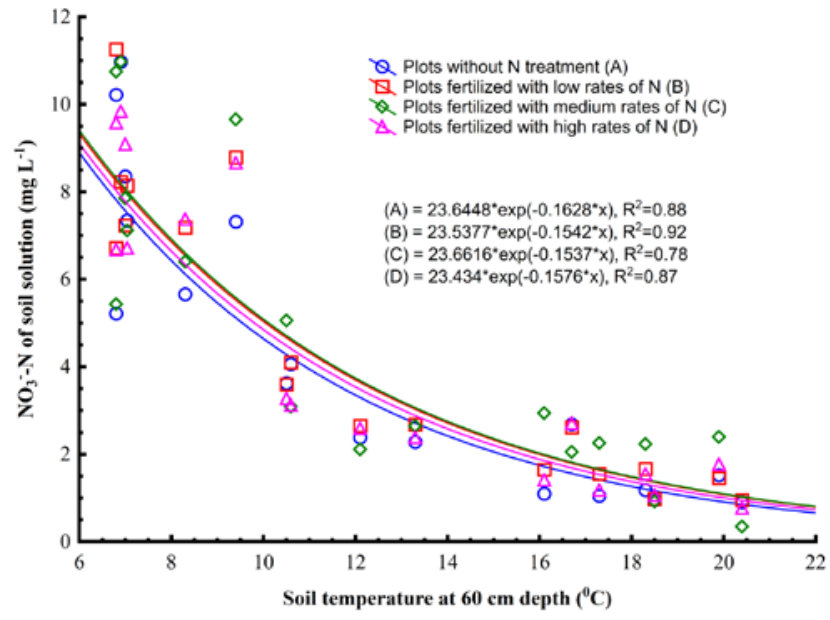

Fig. 3. Relationship between $\mathrm{NO}_{3}{ }^{-} \mathrm{N}$ concentration in soil water extracted with ceramic cups and soil temperature

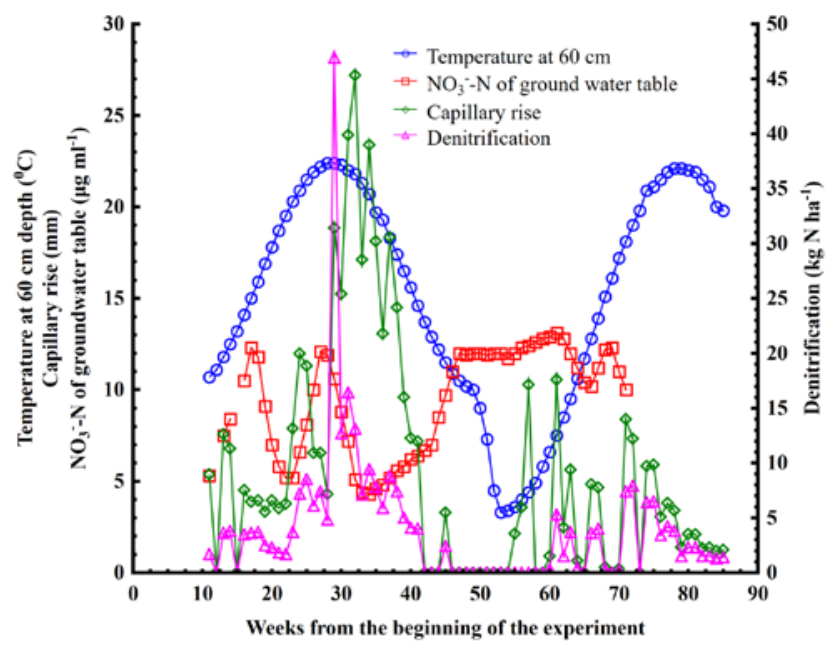

Fig. 4. $\mathrm{N}$ losses $\left(\mathrm{N}_{\mathrm{gas}}\right)$ from denitrification $\left(\mathrm{N}_{\mathrm{den}}\right)$, soil temperature at $60 \mathrm{~cm}$ depth, amount of capillary water raise to the root zone and $\mathrm{NO}_{3}-\mathrm{N}$ concentration of ground water

\section{Loss of $\mathrm{Nas} \mathrm{NH}_{3}\left(\mathrm{~N}_{\text {gas }}\right)$}

The amount of $\mathrm{N}$ lost from ammoniacal fertilizers is the result of a combination of soil properties $(\mathrm{pH}$, particle size distribution, cation exchange capacity, equivalent $\mathrm{CaCO}_{3}$; fertilizer type, quantity and means of application; and climatic conditions (Sommer et al., 2004)). For the studied soil, the $\mathrm{CaCO}_{3}(52.5 \%)$ and $\mathrm{pH}(7.7)$ were at levels, which favour the loss of $\mathrm{N}_{\text {as }} \mathrm{NH}_{3}$ gas.

The highest amount of loss as $\mathrm{NH}_{3}$ was recorded when ammonium fertilizer was applied to the soil surface (Fig. 5). This is in accordance with the findings of Sommer et al. (2004). Relatively low losses of $\mathrm{N}$ occurred at times of the day when soil 
temperature falls and relative humidity rises, i.e. late in the afternoon until early the next morning. A significant loss of $\mathrm{N}$ as $\mathrm{NH}_{3}$ was recorded between $11 \mathrm{am}$ and $4 \mathrm{pm}$, when soil temperature was high and relative humidity low, conditions which favour evaporation. Generally, conditions which favour the loss of water also favour the loss of $\mathrm{N}_{\text {as }} \mathrm{NH}_{3}$ (Sommer $e t$ al., 2004). Consequently, two processes are mainly responsible for $\mathrm{N}$ loss as $\mathrm{NH}_{3}$ : i) conditions which favour the evaporation of water increase the escape of $\mathrm{NH}_{3}$ gas from the soil surface; ii) the upward movement of water due to surface drying facilitates $\mathrm{NH}_{3}$ transport. During the second experiment (May), rainfall of $18 \mathrm{~mm}$ during the second night after fertilizer application was followed by an almost totally cloudless sunny day. This resulted in greater losses of water through evaporation and of $\mathrm{NH}_{3}$ from the experimental plots to which fertilizer had been applied (Fig. 5). Loss of $\mathrm{N}_{\text {as }} \mathrm{NH}_{3}$ was significantly high during the first two days after fertilizer application (Fig. 5). After four days, the loss of $\mathrm{NH}_{3}$ declined massively and measurements ended. The incorporation of the lowest $\mathrm{N}$ treatment $(88 \mathrm{~kg} \mathrm{~N}$ $\mathrm{ha}^{-1}$ ) is the upper $15 \mathrm{~cm}$ of the soil led to the lowest gaseous loss. A significant difference between $\mathrm{NH}_{3}$ losses in April and May existed, with those in May being much higher. The lower soil moisture in May $\left(0.30 \mathrm{~cm}^{3} \mathrm{~cm}^{-3}\right)$ compared with April $(0.40$ $\mathrm{cm}^{3} \mathrm{~cm}^{-3}$ ) on the one hand, and on the other, the higher average soil temperature in May $\left(20^{\circ} \mathrm{C}\right)$ compared with April $\left(14^{\circ} \mathrm{C}\right)$ (Figs. 1(a), 1(b)) resulted in greater losses of $\mathrm{N}_{\text {as }} \mathrm{NH}_{3}$.

\section{Potential mineralization of organic $N\left(N_{\text {min }}\right)$}

$\mathrm{N}_{\min }$ at time $t$ was calculated for the soil layer $0-38 \mathrm{~cm}$ under both laboratory and field conditions. Although the process of mineralization of organic $\mathrm{N}$ can take place at a greater depth, the quantity was not considered significant. The cumulative rate of mineralisation $\left(\mathrm{N}_{\mathrm{cum}}\right)$ decreased over time, under both laboratory and field conditions (Fig. 6). Entering the laboratory
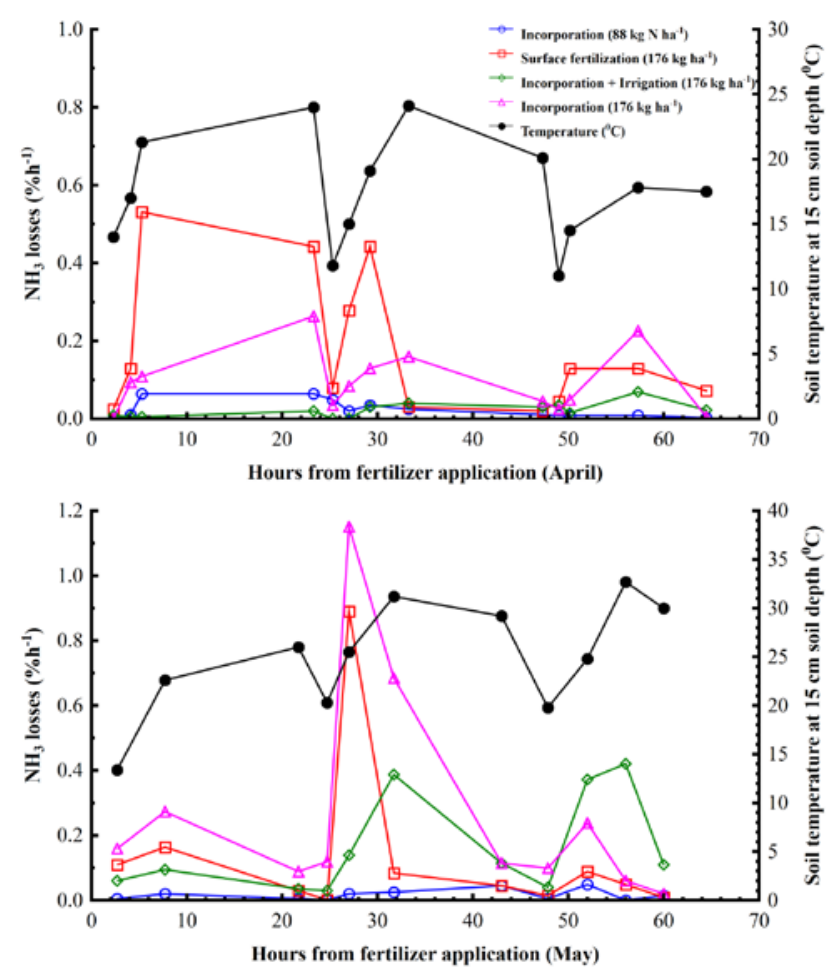

Fig. 5. $\mathrm{NH}_{3}$ losses $\left(\mathrm{N}_{\text {gas }}\right)$ under different modes, rates and time of applied $\mathrm{NH}_{4}$ data into the equation for the first-order reaction $\mathrm{N}_{\text {cum }}=\mathrm{N}_{\min }$ $\left(1-\mathrm{e}^{(-\mathrm{kt})}\right)$ Stanford and Smith (1972) showed that the equation was successful. Although the field temperatures measured at the time of $\mathrm{N}_{\mathrm{cum}}$ determination during the first cultivation period were higher $\left(18.7-26.4^{\circ} \mathrm{C}\right)$ than the lowest temperature used for laboratory soil incubation $\left(7^{\circ} \mathrm{C}\right), \mathrm{N}_{\mathrm{cum}}$ was actually lower ( $80.7 v s .97 .8 \mathrm{mg} \mathrm{kg}^{-1}$ soil). These differences are clearly the result of more favourable soil moisture conditions in the laboratory setting. During the incubation experiment in the field, soil moisture was $28.5-36.9 \%$, while in the laboratory it remained stable at field capacity (44.5\%).

$\mathrm{N}_{\min }$ as calculated using the equation of Stanford and Smith was 88.4 and $106 \mathrm{mg} \mathrm{kg}^{-1}$ soil for the field and laboratory $\left(7^{\circ} \mathrm{C}\right)$ conditions, respectively. $\mathrm{N}_{\min }$ for the rhizosphere was calculated as $257 \mathrm{~kg} \mathrm{ha}^{-1}$, resulting in $10 \%$ lower yields in plots which did not receive $N$ fertilizer compared with that which received the highest $\left(287.4 \mathrm{~kg} \mathrm{ha}^{-1}\right)$. During the subsequent cultivation period (wheat), $\mathrm{N}_{\min }$ in the field decreased significantly to $128.6 \mathrm{~kg} \mathrm{ha}^{-1}$ due to low temperatures and unusual weather conditions during spring and summer. $\mathrm{N}_{\text {min }}$ during the winter period was about 3-fold lower than during the spring (Fig. 1(c)). $\mathrm{N}_{\min }$ was predicted well during the spring and summer, and for both cultivation periods using the equation of Stanford and Smith, adjusted accordingly by calculated soil temperature and moisture (Figs. 1(a), 1(b), and 6). Correct prediction of soil temperature and moisture are critical for the correct prediction of $\mathrm{N}_{\text {min. }}$. Overestimation of $\mathrm{N}_{\min }$ (by 34\%) at the end of autumn and during winter can be attributed to immobilization of N (De Bruin et al. 1989) and possible dependence of $k$ not only on temperature but also on the composition of organic matter (El-Harris et al., 1983). At the end of the first cultivation period fresh columns were installed in the experiment field to investigate changes in mineralisation after incorporation of plant residues (mostly roots and some leaves) and $\mathrm{N}$ mineralisation was measured for 28 weeks. As can be seen from Table $5, \mathrm{~N}_{\min }$ for columns installed after the first cultivation period compared with those installed at its beginning was higher.

\section{Residual soil $N$}

Fig. $8\left(1^{\text {st }}\right.$ sampling $)$ shows that at the beginning of the first cultivation period (March), the amount of residual $\mathrm{NO}_{3}-\mathrm{N}$ was low. During this period, the greatest values of residual $\mathrm{NO}_{3}$

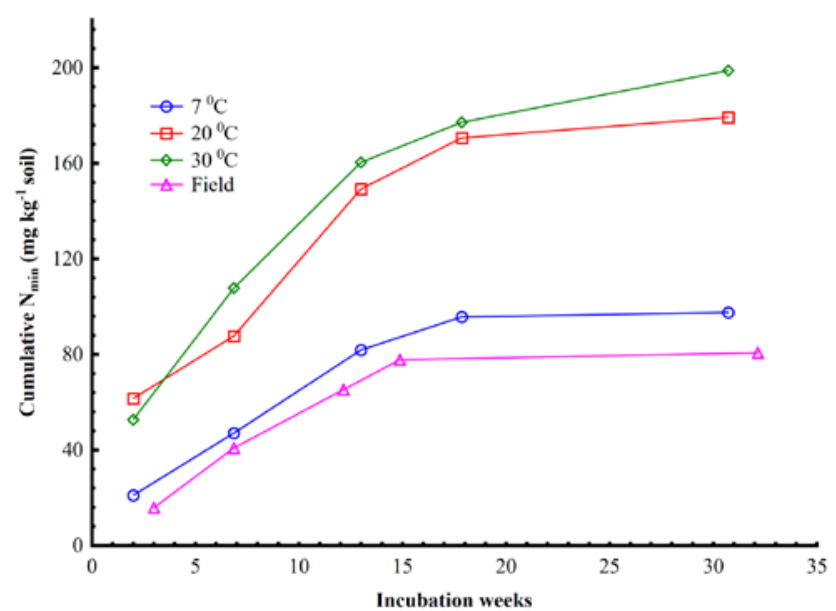

Fig. 6. Cumulative $\mathrm{N}$ mineralized $\left(\mathrm{N}_{\text {min }}\right)$ under laboratory and field conditions 
146

Table 4. Total ammonia volatilization losses $\left(\mathrm{NH}_{3}\right)$ under different rates and modes of applied $\mathrm{N}$

\begin{tabular}{cccc}
\hline \multirow{2}{*}{$\begin{array}{c}\text { Amount of } \mathrm{N} \\
\text { applied in } \\
\text { fertilizer } \\
\left(\mathrm{kg} \mathrm{ha}^{-1}\right)\end{array}$} & $\begin{array}{c}\text { Mode of fertilizer } \\
\text { application }\end{array}$ & \multicolumn{2}{c}{ Total NH $\mathrm{H}_{3}$ losses } \\
\cline { 3 - 4 } & Carving & 0 & May \\
\hline 0 & Incorporation & 0.8 & 1.0 \\
88 & $\begin{array}{c}\text { Incorporation } \\
176\end{array}$ & 3.3 & 2.8 \\
176 & $\begin{array}{c}\text { Incorporation } \\
\text { and irrigation }\end{array}$ & 1.3 & 10.3 \\
176 & Surface application & 6.7 & 12.1 \\
\hline
\end{tabular}

Table 5. Total $\mathrm{N}$ mineralized $\left(\mathrm{N}_{\min }\right)$ under field conditions measured in soil columns at the beginning and end of the end of the first growing season (maize)

\begin{tabular}{|c|c|c|}
\hline Time & \multicolumn{2}{|c|}{$\begin{array}{l}\text { Total } \mathrm{N} \text { mineralized in soil columns installed in the field during } \\
\text { maize cultivation }\end{array}$} \\
\hline \multirow{2}{*}{ Weeks } & Start of the growing period & End of the growing period \\
\hline & \multicolumn{2}{|c|}{$\mathrm{mg} \mathrm{kg}^{-1}$ soil } \\
\hline 4.4 & $0.6 a^{*}$ & $2.4 \mathrm{~b}$ \\
\hline 10.4 & $2.4 \mathrm{c}$ & $7.6 \mathrm{~d}$ \\
\hline 20.0 & $6.3 \mathrm{e}$ & $17.6 \mathrm{f}$ \\
\hline 28.8 & $14.3 \mathrm{~g}$ & $32.8 \mathrm{~h}$ \\
\hline
\end{tabular}

${ }^{*}$ Numbers in the same column followed by the same letter are not significantly different according to Duncan multiple range test at $\mathrm{p}<0.05$

Table 6. $\mathrm{N}$ inputs $\left(\mathrm{N}_{\text {init }}, \mathrm{N}_{\text {min }}, \mathrm{N}_{\text {fert }}, \mathrm{N}_{\text {atm }+ \text { irr }}, \mathrm{N}_{\text {cap. }}\right), \mathrm{N}$ outputs $\left(\mathrm{N}_{\text {res }}, \mathrm{N}_{\text {upt. }}, \mathrm{N}_{\text {vol }}, \mathrm{N}_{\text {leac }}, \mathrm{N}_{\text {den }}\right)$ and apparent losses (Nt ) in a maize - wheat cropping system with different $\mathrm{N}$ treatments

\begin{tabular}{|c|c|c|c|c|c|c|c|c|c|c|c|}
\hline \multirow{2}{*}{$\begin{array}{l}\text { N Treatment } \\
\left(\mathrm{kg} \mathrm{ha}^{-1}\right)\end{array}$} & \multicolumn{5}{|c|}{$\mathrm{N}$ Inputs $\left(\mathrm{kg} \mathrm{ha}^{-1}\right)$} & \multicolumn{6}{|c|}{ N Outputs $\left(\mathrm{kg} \mathrm{ha}^{-1}\right)$} \\
\hline & $\mathrm{N}_{\text {init }}$ & $\mathrm{N}_{\min }$ & $\mathrm{N}_{\text {fert }}$ & $\begin{array}{c}\mathrm{N}_{\mathrm{atm}}+ \\
\mathrm{N}_{\text {irr }}\end{array}$ & $\mathrm{N}_{\text {cap }}$ & $\mathrm{N}_{\text {resid }}$ & $\mathrm{N}_{\text {upt }}$ & $\mathrm{N}_{\mathrm{vol}}$ & $\mathrm{N}_{\text {leac }}$ & $\mathrm{N}_{\text {den }}$ & $\mathrm{Nt}$ \\
\hline \multicolumn{12}{|c|}{$1^{\text {st }}$ Growing period (Maize) } \\
\hline 0 & 18 & 411 & 0 & 8 & 3 & 29 & 255 & 0 & 6 & 18 & 132 \\
\hline 95 & 19 & 411 & 95 & 8 & 3 & 28 & 296 & 0 & 31 & 18 & 142 \\
\hline 193 & 16 & 411 & 192 & 8 & 3 & 57 & 296 & 8 & 32 & 18 & 219 \\
\hline 287 & 19 & 411 & 287 & 8 & 3 & 103 & 316 & 13 & 40 & 18 & 238 \\
\hline \multicolumn{12}{|c|}{$2^{\text {nd }}$ Growing period (Wheat) } \\
\hline 0 & 29 & 240 & 0 & 5 & 4 & 23 & 89 & 0 & 92 & 7 & 69 \\
\hline 47 & 28 & 240 & 47 & 5 & 4 & 22 & 152 & 0 & 96 & 7 & 49 \\
\hline 80 & 57 & 240 & 80 & 5 & 4 & 22 & 169 & 3 & 118 & 7 & 68 \\
\hline 128 & 103 & 240 & 128 & 5 & 4 & 24 & 206 & 4 & 175 & 7 & 66 \\
\hline
\end{tabular}

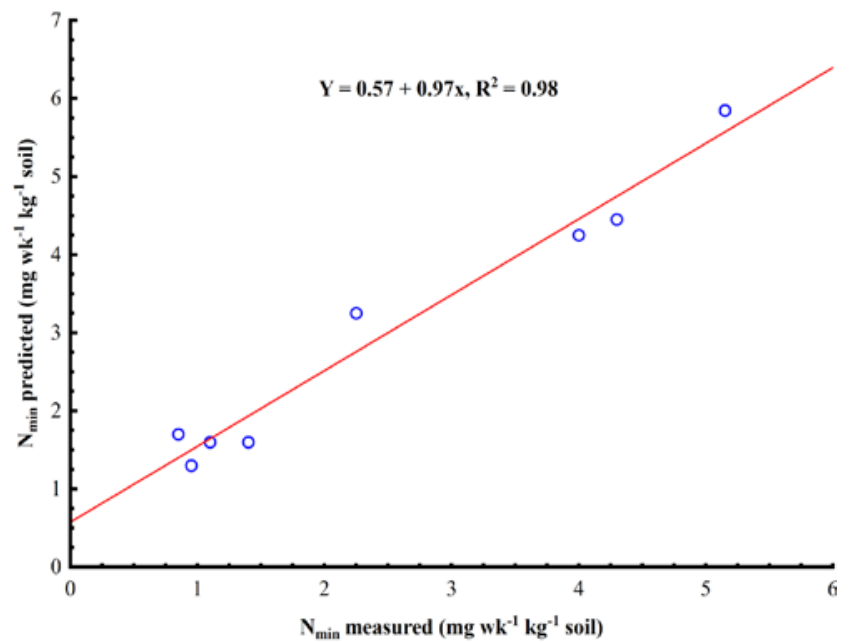

Fig. 7. Predicted and measured values of $\mathrm{N}$ mineralized $\left(\mathrm{N}_{\min }\right)$ under field conditions

$-\mathrm{N}$ were found for the $38-72 \mathrm{~cm}$ layer, immediately below the root zone. The low values for $\mathrm{NO}_{3}^{-}-\mathrm{N}$ and its distribution in the soil profile during spring indicate its leaching during the winter. Approximately in the middle of the cultivation period, high amounts of $\mathrm{NO}_{3}-\mathrm{N}$ were found in the upper $15 \mathrm{~cm}$ of the soil profile due to the preceding fertilizer application, while below $38 \mathrm{~cm}$ the concentration declined abruptly (Fig. 8, $2^{\text {nd }}$ sampling). This pattern was found for all treatments. Leaching of $\mathrm{NO}_{3}^{-}-\mathrm{N}$ during this period was minimal due to the lack of rain and of irrigation. Notably, there was a significant increase in $\mathrm{NO}_{3}-\mathrm{N}$ in the surface horizon of the experimental plots which did not receive fertilizer. The increase in $\mathrm{NO}_{3}-\mathrm{N}$ content in this horizon, despite removal of $\mathrm{NO}_{3}-\mathrm{N}$ by the crop, should be the result of mineralisation of $\mathrm{N}$ during this period (Figs. 1(c) and 7). At the end of the first cultivation period (Fig. 8, $3^{\text {rd }}$ sampling), the $\mathrm{NO}_{3}-\mathrm{N}$ had practically all been consumed in plots which had received no fertilizer or 94.6 $\mathrm{kg} \mathrm{N} \mathrm{ha}{ }^{-1}$, while $\mathrm{NO}_{3}-\mathrm{N}$ representing $9.2 \%$ and $14.37 \%$ of applied $\mathrm{N}$ remained in soil in plots which received 193 and $287.4 \mathrm{~kg} \mathrm{~N}^{-1}{ }^{-1}$, respectively. The $\mathrm{NO}_{3}-\mathrm{N}$ content of soil below the root zone was quite low (Fig. 8), due to the high level of denitrification recorded during the warm summer.

At the beginning of the second cultivation period (Fig. 9, $4^{\text {th }}$ sampling), the distribution of $\mathrm{NO}_{3}-\mathrm{N}$ in the soil profile shows the movement of $\mathrm{NO}_{3}-\mathrm{N}$, through leaching to deeper layers due to moderate rainfall $(86.3 \mathrm{~mm})$ during this period. As a result of two major rainfall events approximately in the middle of the second cultivation period, a great quantity of $\mathrm{NO}_{3}-\mathrm{N}$ was leached to groundwater (Fig. 9, $5^{\text {th }}$ sampling). At the end of the cultivation period, there was practically no rainfall, and leaching was therefore not possible (Fig. 9, $6^{\text {th }}$ sampling).

\section{NInput - Output}

At the beginning of the experiment, the residual $\mathrm{N}\left(\mathrm{N}_{\mathrm{res}}\right)$ in the rhizosphere $(0-38 \mathrm{~cm})$, considered to be the initial $\mathrm{N}\left(\mathrm{N}_{\text {init }}\right)$ in the calculations, did not differ significantly between experimental plots $\left(18 \pm 1.4 \mathrm{~kg} \mathrm{~N} \mathrm{ha}^{-1}\right)$. At the end of the first cultivation period, after maize harvest, $\mathrm{N}_{\mathrm{rec}}$ was $29,28,27,57$, $103 \mathrm{~kg} \mathrm{~N}^{-1}$ for $0,95,193$ and $287 \mathrm{~kg} \mathrm{~N}^{-1}$, respectively, indicating increasing $\mathrm{N}_{\text {res }}$ with increasing $\mathrm{N}_{\text {fert }}(\mathrm{r}=0.92, \mathrm{p}<$ 0.001 ). At the end of the second cultivation period, $N_{r e s}$ did not differ significantly by treatment, indicating that a significant proportion of $\mathrm{N}$ had been leached to deeper soil layers during the winter. 

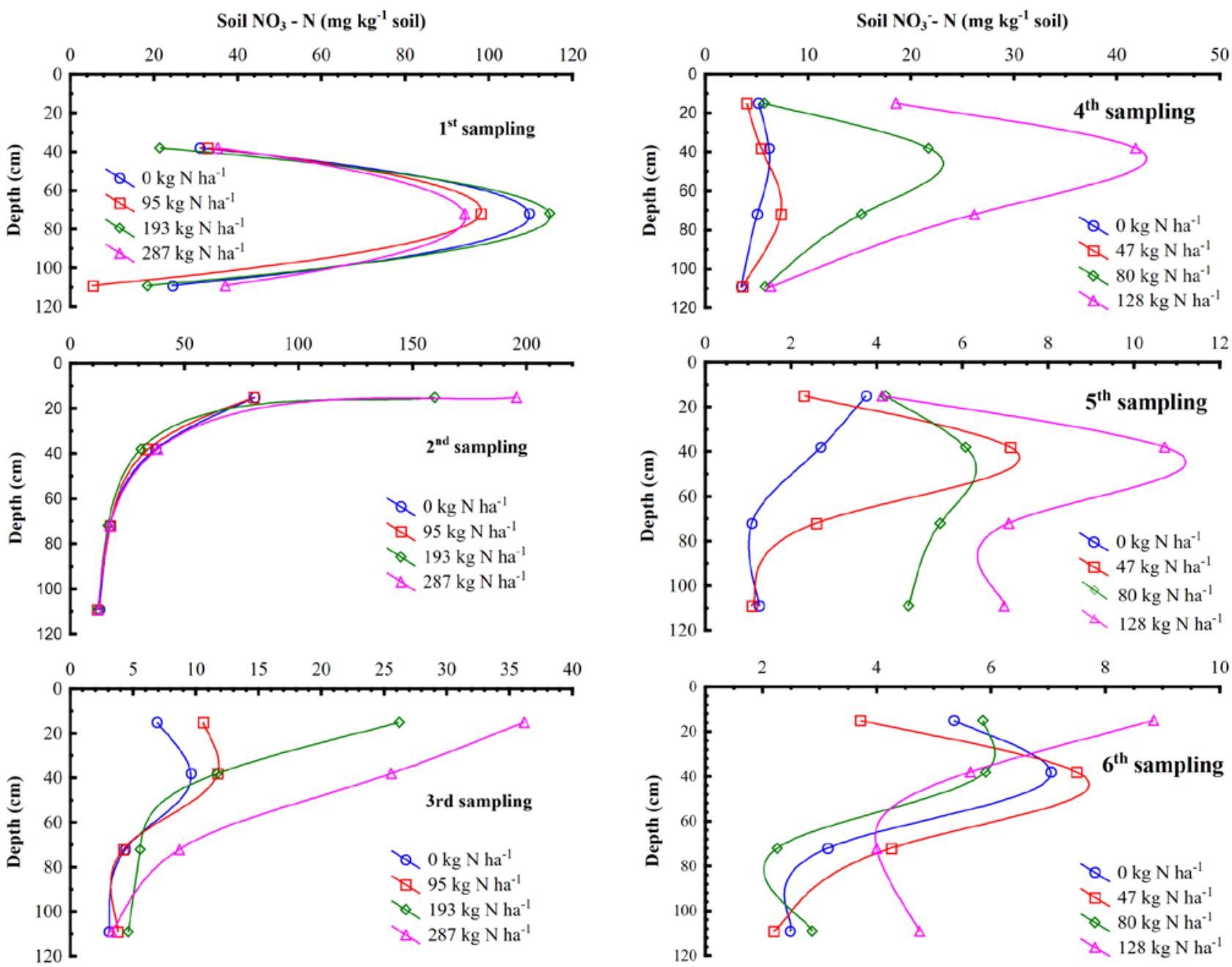

Fig. 8. $\mathrm{NO}_{3}^{-}-\mathrm{N}$ distribution with soil depth under different rates of $\mathrm{N}$ fertilizer applications at different growth stages of plant, during the first study period (maize)

The outputs $\mathrm{N}_{\text {upt }}$ and $\mathrm{N}_{\mathrm{res}}$, which represent the "apparent losses", increased with increasing $\mathrm{N}_{\text {fert }}$ during the first $(\mathrm{r}=0.88$, $\mathrm{p}<0.001)$ and second $(\mathrm{r}=0.85, \mathrm{p}<0.001)$ cultivation period but also for the whole study period $(\mathrm{r}=0.92, \mathrm{p}<0.001)$, indicating the increase of these $\mathrm{N}$ outputs with increasing $\mathrm{N}_{\text {fert. }}$. The apparent losses during the second cultivation period did not differ significantly from those of the first. However, $\mathrm{N}_{\mathrm{lea}}$ was significantly greater than during the first and contributed to the apparent losses by more than $55 \%$, showing that these losses of $\mathrm{N}$ were mainly due to leaching. The losses of $\mathrm{N}$ in gaseous form $\left(\mathrm{N}_{\mathrm{gas}}+\mathrm{N}_{\mathrm{den}}\right)$ were less than those of the first cultivation period. The statistically significant correlation between apparent losses and $\mathrm{N}_{\mathrm{leac}}$ not only for the first $(\mathrm{r}=$ $0.88, \mathrm{p}<0.001)$ and second $(\mathrm{r}=0.85, \mathrm{p}<0.001)$ cultivation period but also for the whole study period $(r=0.92, p<0.001)$ supports the conclusion that leaching is the primary route of $\mathrm{N}$ loss in this agricultural ecosystem.

\section{Conclusions}

The total $\mathrm{N}$ balance $(\mathrm{Nt})$ for each cultivation period reveals a significant deficit, which can be attributed to forms of $\mathrm{N}$

Fig. 9. $\mathrm{NO}_{3}-\mathrm{N}$ distribution with soil depth under different rates of $\mathrm{N}$ fertilizer applications at different growth stages of plant, during the second study period (wheat)

which were not possible to be included in this study. Losses of these forms of $\mathrm{N}$ were relatively high, especially during the first cultivation period, leading to the conclusion that a significant amount of $\mathrm{N}$ was immobilized or taken up by weeds.

The potential $\mathrm{N}$ for this soil showed that high values of $\mathrm{N}_{\text {leac }}$ were the result of the application of high quantities of nitrogenous fertilizer.

The losses of $\mathrm{N}$ from the root zone $(<38 \mathrm{~cm})$ in gaseous form and from denitrification were relatively low compared with losses by leaching. The reduction of losses of $\mathrm{N}$ by leaching requires accurate estimation of demands for nitrogen by plants under intensively cultivated agroecosystems.

$\mathrm{N}_{\min }$ was found to be a significant input into this particular ecosystem, and its values were greater than those for $\mathrm{N}_{\text {upt }}$ for both crops. This input of $\mathrm{N}$ also defines the response of crops to the application of $\mathrm{N}$ fertilizer.

Nitrogen which is taken up and removed by the crops increased with increasing $\mathrm{N}$ fertilization.

For sustainable land use, inputs and outputs of nutrients must be balanced in order to avoid negative impacts on the environment, especially in intensively exploited agricultural ecosystems. 


\section{References}

Allen RG, Pereira LS, Raes D, Smith M (1998). Evapotranspiration Guidelines for computing crop water requirements. FAO Irrigation and drainage paper 56. Water Resources, Development and Management Service FAO. Food and Agriculture Organization of the United Nations Rome.

Berghuijs-van DijkJT (1985). WATBAL, A simplewater balance model for a unsaturated/saturated soil profile. ICW-nota 1670. Wageningen.

Bouma J, Denning JL (1972). Field measurements of unsaturated conductivity by infiltration through gypsum crusts. Soil Science Society America Proceedings 36:846-847.

Crutzen PJ (1981). Atmospheric chemical processes of the oxides of nitrogen, including nitrous oxide. In: Delwiche J (Ed). Denitrification, Nitrification and Nitrous oxide. Wiley New Yorkpp 1744.

Davis R L, Patton JJ, Teal RK, Tang Y, Humphreys MT, Mosali J, ... Raun WR (2003). Nitrogen balance in the Magruder plots following 109 years in continuous winter wheat. Journal of Plant Nutrition 26:15611580.

De Bruin B, Penning de Bries FWT, van Broekhoven LW, Vertregt N, van De Geijn SC (1989). Net nitrogen mineralization, nitrification and $\mathrm{CO}_{2}$ production in alternating moisture conditions in an unfertilized low-humus sandy soil from the Sahel. Plant and Soil 113:69-78.

Driessen PM (1988). The Q.L.E. Primer. Bodenkunde en Geologie. Landbouwuniversiteit, Wageningen The Netherlands.

EEC (1991). Protection of water against pollution by nitrates from agriculture. EEC/91/976, Official Journal No L375, 31/12/1991, Brussels.

Eickhout B, Bouwman AP, van Zeijts H (2006). The role of nitrogen in world food production and environmental sustainability. Agriculture, Ecosystems and Environment 116:4-14.

El-Harris MK, Cochran VL, Elliot LF Bezdicek DF (1983). Effect of tillage cropping and fertilizer management on soil nitrogen mineralization potential. Soil Science Society of America Journal 47:1157-1161.

Franzluebbers AJ (2007). Integrated crop-livestock systems in the southeastern USA. Agronomy Journal 99:361-372.

Herrero M, Thorton PK, Notenbaert AM, Wood S, Masangi S, Freeman HA, ... Rosegrant M (2010). Smart investments in sustainable food productions: revisiting mixed crop-livestock systems. Science (327):822825.

Janzen HH, Beauchemin KA, Bruinsma Y, Campbell CA, Desjardins RL, Ellert BH, Smith EC (2003) The fate of nitrogen in agroecosystems: an illustration using Canadian estimates. Nutrient Cycling in Agroecosystems 67:85-102

Keeney DR and Nelson DW (1982). Nitrogen-Inorganic Forms. In: Page AL, Miller RH, Keeney DR(Eds). Methods of Soil Analysis, Part 2, 2 ${ }^{\text {nd }}$ Ed Agronomy 9. Agronomy Society America and Soil Science Society of America Madison WI pp 643-698.
Kissel DE, Brewer HL, Arkin GF (1977). Design and test of a field sampler for ammonia volatilization. Soil Science Society of America Journal 41(6):1133-1138.

Manzoni S, Porporato A (2009). Soil carbon and N-mineralization: Theory and models across scales. Soil Biology and Biochemistry 41:1355-1379.

Meisinger JJ, Randall GW (1991). Estimating nitrogen budgets for soil-crop systems. In: Follett RF (Ed). Managing Nitrogen for Groundwater Quality and Farm Profitability. Soil Science Society of America Madison WIpp 85-124.

Merrington G, Winder L, Parkinson R, Redman M (2002). Agricultural Pollution: Environmental Problems and Practical Solutions. Spon Press, London.

Pieri L, Ventura F, Vignudelli M, Rossi P (2011). Nitrogen balance in a hilly semiagricultural watershed in northern Italy. Italian Journal of Agronomy 6:67-75.

Ross SM, Izaurralde RC, Janzen HH, Robertson JA, McGill WB (2008). The nitrogen balance of three long-term agroecosystems on a boreal soil in western Canada. Agriculture Ecosystem Environment 127:241-250.

Scott H.D (2000). Soil physics. Iowa State University Press, Ames Iowa.

Soil Survey Laboratory Methods Manual (2014). Soil Survey Investigations Report No.42, version 5.0, United States Department of Agriculture.

Soil Survey Staff (1975). Soil Taxonomy: A basic system of soil classification for making and interpreting soil surveys. Agric. Handbook No 436, USDA-SCS. U.S. Government PrintingOffice Washington DC.

Sommer GS, Schjoerring JK, Denmead OT (2004). Ammonia emission from mineral fertilizers and fertilized crops. Advances in Agronomy 82:557-623.

Stanford G, Smith SJ (1972). Nitrogen mineralization potentials of soils. Soil ScienceSociety America Journal 36:465-472.

STATSOFT Inc (1995). Statistica for Windows. Tulsa, OK. StatSoft, Inc., Tulsa, OK.

Talpaz H, Fine P. Bar-Yosef B (1981). On the estimation of Nmineralization parameters from incubation experiments. Soil Science Society America Journal 45:993-996.

Vanclooster M, Vereecken H, Diels J, Huysmans F, Verstrate W, Feyen (1992). Effect of mobile and immobile water in predicting nitrogen leaching from cropped soils. Modelling Geo-Biosphere Proceedings 1:23-40.

Vereecken H, Schnepf A, Hopmans JW, Javaux M, Or D, Roose T, ... Young IM (2016). Modelingsoil processes: Review, Key Challenges and New Perspectives. VandoseZone Journal 15:1-57.

Yates ND (1996). WATBAL: An integrated water Balance Model for Climate impact assessment of river basin runoff. International Journal of Water Resources Development 12(2):121-139. 